\title{
EVALUASI PENERAPAN DANA KAS KECIL PADA PT. PUTRA KARANGETANG
}

\author{
Mega Eliza Wongkar ${ }^{1}$, Grace B. Nangoi ${ }^{2}$, Steven J. Tangkuman ${ }^{3}$ \\ ${ }^{1,2,3}$ Jurusan Akuntansi, Fakultas Ekonomi dan Bisnis, Universitas Sam Ratulangi, Jl. Kampus Unsrat, Manado, \\ 95115, Indonesia \\ E-mail : wongkarm@gmail.com
}

\begin{abstract}
Petty cash is a cash amount owned by the company and is held or managed by a cashier whose function is to pay or finance expenses that are relatively small and tend to be routine and are immediate. The object of this research is PT. Putra Karangetang. The purpose of this research is to study how the application of accounting petty cash at the company. A data analysis method used in this research is descriptive method, which is carried out by means of collecting data related to problems encountered and serves the description of how to systematically and accurately about the facts, the nature of the relationships between phenomena investigated in a company. The results showed that the method used in the completion of petty cash fund by PT. Putra Karangetang is the fluctuation fund method, where in this method the balance of the petty cash account is not fixed (fluctuate), the number of refund is not in accordance with the expenditures of petty cash.

Keywords : Accounting, Petty cash fund
\end{abstract}

\section{PENDAHULUAN}

Persaingan dunia bisnis di Indonesia saat ini sangatlah ketat. Berbagai jenis perusahaan bermunculan yang bergerak dibidang yang berbeda-beda seperti bidang jasa, dagang, maupun manufaktur yang saling bersaing untuk dapat bertahan dan menjadi yang terbaik, hal ini mendorong masing-masing perusahaan untuk melakukan berbagai strategi agar terhindar dari kesulit keuangan.Dalam perkembangan dunia usaha sendiri diperlukan sikap profesionalis dari setiap elemen yang ada dalam perusahaan serta suatu control agar semua kegiatan berjalan sebagaimana mestinya, hal ini sangat penting agar perusahaan dapat menjaga kelangsungan hidupnya. Sikap profesional tersebut dapat tercermin dari kemampuan perusahaan untuk bersaing dipasar, yaitu strategi dimana perusahaan dapat memanfaatkan semua peluang dan kekuatan yang ada dan mampu menutup kelemahan serta menetralisir hamabatan, serta memiliki strategi dalam dinamika bisnis yang dihadapi.

Semakin berkembangnya perusahaan baik kegiatan maupun jumlah karyawan, pimpinan perusahaan tidak dapat lagi melaksanakan sendiri semua fungsinya, kondisi semacam ini menuntut pimpinan perusahaan untuk mendelegasikan sebagian tugas, wewenang serta tanggung jawab kepada beberapa bawahan yang dipimpinnya guna membantu pengelolaan perusahaan. Pengelolaan perusahaan yang baik merupakan cermin kesuksesan. Sebuah kesuksesan perusahaan bisa dicapai dengan mengambil keputusankeputusan berdasarkan visi dan misi perusahaan serta tujuan yang pasti agar bisa terarah.

Penerapan sistem akuntansi yang sesuai dengan kondisi dan situasi yang dihadapi perusahaan dapat membantu perusahaan dalam menyediakan data dan informasi yang diperlukan oleh manajemen dalam pengambilan keputusan, melakukan pengawasan, dan mengoperasikan perusaahaan secara efisien. Sadeli (2015: 18), menyatakan laporan keuangan adalah laporan tertulis yang memberikan informasi kuantitatif tentang posisi keuangan dan perubahan-perubahannya, serta hasil yang dicapai selama periode tertentu. Sehingga harus benar-benar relevan dan wajar.

Hampir seluruh aktivitas perusahaan berhubungan dengan kas. Kekurangan atau kelebihan kas menimbulkan berbagai masalah. Kas yang menganggur selain menimbulkan 
risiko penggelapan atau kecurangan dan juga akan menimbulkan kerugian penurunan nilai intrinsik. Laporan arus kas yang menjelaskan pengelolaan berupa penerimaan dan penggunaan kas dalam perusahaan dinyatakan sebagai salah satu laporan keuangan pokok yang wajib disusun untuk pengambilan keputusan ekonomi. Laporan arus kas menyajikan aliran kas masuk (cash flow in) dan aliran kas keluar (cash flow out) dalam suatu perusahaan.

Perusahaan yang bergerak baik dibidang jasa, dagang, dan manufaktur selalu dihadapi dengan masalah pengelolahan dan pengawasan harta bendanya. Terutama dalam pengolahan harta perusahaan yang berbentuk kas. Kas adalah komponen aktiva yang paling aktif dan sangat mempengaruhi setiap transaksi yang terjadi.

Kas adalah harta perusahaan yang sangat penting dan likuid karena merupakan alat pembayaran atas setiap pembayaran yang dilakukan. Kas paling banyak terlibat dalam transaksi-transaksi perusahaan. Hal ini disebabkan sifat-sifat transaksi perusahaan yang mencakup harga dan kondisi yang memerlukan pengelolahan dalam bentuk bahasa dan alat tukar. Alat tukar yang dimaksud adalah uang. Kas terlibat langsung dalam transaksi ataupun kegiatan perusahaan, baik itu dalam bentuk penerimaan maupun bentuk pengeluaran kas. Hal ini sangat diperlukan perhatian khusus karena berkaitan dengan kemampuan perusahaan dalam mengelola kekayaan yang dimiliki. Kas adalah kekayaan yang dimiliki oleh perusahaan yang memiliki risiko tinggi. Kas merupakan jenis aktiva yang mempunyai risiko tinggi untuk dijadikan sasaran kecurangan, karena kas sendiri merupakan aktiva perusahaan yang paling liquid, mudah digelapkan dan diselewengkan serta dipindahtangankan.

Pembentukan dana kas kecil (petty cash fund) untuk membiayai pengeluaranpengeluaran yang jumlahnya relatif kecil dan transaksi relatif banyak dan bersifat segera. Dana kas kecil ini ditangani oleh seorang pengelola kas kecil yang telah ditunjuk oleh perusahaan. Walaupun jumlah dana yang dikelola dalam dana kas kecil ini relatif kecil, akan tetapi penanganannya harus tetap dilakukan dengan baik.

Kas kecil adalah sejumlah uang tunai yang dimiliki perusahaan dan dipegang atau dikelola oleh kasir yang fungsinya untuk pembayaran ataupun pembiayaan pengeluaranpengeluaran yang sifatnya relatif kecil dan cenderung rutin serta bersifat segera. Transaksitransaksi yang rutin yang terjadi tanpa pengelolaan dan metode penerapan yang kurang baik serta kurang pengendalian yang tepat dapat menyebabkan tindakan dan masalah yang dapat membuat perusahaan kurang maksimal dalam menggunakan kekayaan perusahaan.

Sistem dana kas kecil yang diterapkan pada perusahaan tidak dapat berjalan dengan baik apabila tidak diimbangi dengan sistem pengendalian intern yang baik pula. Sistem Pengendalian Intern dalam suatu perusahaan meliputi struktur organisasi yang melakukan pemisahan tanggung jawab, sistem otorisasi, praktik yang sehat, serta karyawan yang memiliki kemampuan dibidangnya. Sistem pengendalian intern dimaksudkan untuk menghindari tindakan kecurangan yang dilakukan oleh karyawan

\section{TINJAUAN PUSTAKA}

Akuntansi adalah sebuah informasi yang mengukur aktivitas bisnis, pemrosesan dan menjadi laporan, dan mengkomunikasikan hasilnya pada para pengambil keputusan (Horngren, et al., 2012 dikutip oleh Winston 2013). Menurut A Statement of Basic Accounting Theory (ASOBAT) yang diterbitkan oleh American Accounting Association (AAA) pada tahun 1966, akuntansi didefinisikan sebagai proses mengidentifikasi, mengukur, dan menyampaikan informasi ekonomi bagi para penggunanya dalam mempertimbangkan berbagai alternative yang ada dan membuat kesimpulan (Hery, 2013 : 3). Menurut American Institute of Certified Public Accountants(AICPA) "Akuntansi adalah seni pencatatan, pengklasifikasian, dan pengikhtisaran dalam cara yang signifikan dan satuan mata uang, transaksi-transaksi dan kejadian-kejadian yang, paling tidak sebagaian diantaranya, memiliki sifat keuangan, dan selanjutnya menginterpretasikan hasilnya (Belkaoui, 2012 : 50). 
Akuntansi merupakan seni pencatatan, pengklasifikasi, pengikhtisaran suatu informasi mengenai entitas ekonomi sehingga memperoleh suatu informasi berupa laporan keuangann yang berguna bagi pengambilan keputusan untuk pihak yang berkepentingan.

Akuntansi Keuangan (Financial Accounting) sangat terkait dengan pencatatan dan pelaporan data dan aktivitas ekonomi suatu perusahaan (Revee, et al, 2013 : 10). Akuntansi keuangan adalah bagian dari akuntansi yang menyediakan informasi ekonomi dan informasi keuangan kepada investor, kreditor, dan pengguna eksternal lainnya (Weygant, et al, 2015 : 6). Kieso, et al. (2014 : 5) menyatakan bahwa akuntansi keuangan (financial accounting) adalah proses yang berujung pada persiapan laporan keuangan perusahaan untuk digunakan oleh baik pihak internal dan pihak eksternal perusahaan. Akuntansi Keuangan (Financial Accounting) berfokus pada pengembangan dan pengomunikasian informasi kuangan kepada pengguna eksternal (Stice dan Stice, 2014 : 5). Akuntansi keuangan merupakan proses yang menghasilkan laporan keuangan perusahaan secara menyeluruh yang dibutuhkan oleh pihak internal maupun pihak eksternal perusahaan atau organisasi dalam rangka pengambilan keputusan.

Laporan keuangan (financial statement) merupakan produk akhir dari serangkaian proses pencatatan dan pengikhtisaran data transaksi bisnis (Hery, 2016 : 3). Laporan keuangan pada dasarnya merupakan hasil dari proses akuntansi yang dapat digunakan sebagai alat untuk mengomunikasikan data keuangan kepada pihak-pihak yang berkepentingan. Dengan kata lain, laporan keuangan ini berfungsi sebagai alat informasi yang menghubungkan perusahaan dengan pihak-pihak yang berkepentingan, yang menunjukkan kondisi kesehatan keuangan perusahaan dan kinerja perusahaan.

Financial statement (laporan keuangan) adalah prinsip-prinsip yang memungkinkan perusahaan menyampaikan informasi keuangannya kepada pihak luar (Kieso, et al. 2014 : 5). Laporan keuangan yang sering disediakan yaitu (1) the statement of financial position (laporan posisi keuangan), (2) the income statement atau statement comprehensive income (laporan laba/rugi), (3) the statement of cash flow (laporan arus kas), dan (4) the statement of changes in equity (laporan perubahan modal). Laporan keuangan adalah proses mengomunikasikan informasi akuntansi keuangan kepada investor, kreditor, dan pihak eksternal lainnya untuk mengambil keputusan (Wahlen, et al. $2015: 6$ ).

Tujuan laporan keuangan adalah menyediakan informasi yang menyangkut posisi keuangan, kinerja serta perubahan posisi keuangan suatu perusahaan yang bermanfaat bagi sejumlah besar pemakai dalam pengambil keputusan ekonomi, serta hasil yang dicapai selama periode tertentu. Tujuan keseluruhan dari laporan keuangan adalah untuk memberikan informasi yang berguna bagi investor dan kreditor dalam pengambilan keputusan investasi dan kreditor dalam pengambilan keputusan investasi dan kredit (Hery, $2016: 4$ ).

Tujuan khusus laporan keuangan adalah menyajikan secara wajar dan sesuai dengan prinsip-prinsip akuntansi yang berlaku umum mengenai posisi keuangan, hasil usaha, dan perubahan lain dalam posisi keuangan. Sedangkan dalam Standar Akuntansi Keuangan dijelaskan tentang tujuan laporan keuangan yang isinya "Tujuan laporan keuangan, kinerja, serta perubahan posisi keuangan suatu perusahaan, yang bermanfaat bagi sejumlah besar pemakai dalam pengambilan keputusan ekonomi (Hery 2013 : 12)".

Analisis laporan keuangan merupakan suatu proses untuk membedah laporan keuangan ke dalam unsur-unsurnya dan menelaah masing-masing dari unsur tersebut dengan tujuan untuk memperoleh pengertian dan pemahaman yang baik dan tepat atas laporan keuangan itu sendiri (Hery, 2016 : 113). Analisis terhadap laporan keuangan suatu perusahaan pada dasarnya karena ingin mengetahui tingkat profitabilitas (keuntungan) dan tingkat risiko atau tingkat kesehatan suatu perusahaan (Hanafi dan Halim, 2016 : 5).

PSAK no. 1 paragraf ke 09 (Revisi 2015), menyatakan "Tujuan laporan keuangan adalah memberikan informasi mengenai posisi keuangan, kinerja keuangan dan arus kas 
entitas yang bermanfaat bagi sebagian besar pengguna laporan dalam pembuatan keputusan ekonomik". Dalam rangka mencapai tujuan tersebut, laporan keuangan menyajikan informasi mengenai entitas yang meliputi :
a) asset,
b) liabilitas,
c) ekuitas,
d) pendapatan dan beban termasuk keuntungan dan kerugian,
e) kontribusi dari dan distribusi kepada pemilik dalam kapasitasnya sebagai pemilik, dan
f) arus kas.

Kas hanya diartikan sebagai mata uang yang digunakan sebagai alat pembayaran dan alat pertukaran. Berdasarkan pengertian akuntansi, kas meliputi uang dan alat pembayaran lain yang disamakan dengan uang atau pembayaran untuk mempermudah jalannya transaksi. Disamping itu, kas juga merupakan suatu aktiva yang mudah diselewengkan dan disalahgunakan oleh karyawan, karena kas merupakan aktiva yang paling mudah dipindahtangankan atau bisa diartikan aktiva yang paling likuid.

Kas kecil merupakan dana kas yang diperlukan untuk memenuhi kebutuhan seharihari, yaitu untuk biaya-biaya yang jumlahnya relatif kecil. Dalam rangka meningkatkan efisiensi dan efektivitas penarikan dana kas yang jumlahnya kecil, maka bank tidak perlu mengeluarkan dana ini berasal dari kas besar akan tetapi perlu disediakan kas kecil.

Dapat dijelaskan secara singkat bahwa kas kecil atau biasa disebut petty cash adalah sejumlah uang tunai yang dimiliki perusahaan dan dipegang atau dikelola oleh kasir kas kecil yang fungsinya untuk membayar pengeluaran-pengeluaran yang sifatnya relatif kecil dan cenderung rutin. Serta memiliki karakteristik : (1) Jumlahnya dibatasi, sesuai dengan rutinitas perusahaan, (2) untuk membayar pengeluaran yang relatif kecil.

Penyelenggaraan dana kas kecil untuk memungkinkan pengeluaran kas dengan uang tunai dapat diselenggarakan dengan 2 cara, yaitu :

1. Metode Dana Berubah (Fluctuating Fund Method)

Metode ini tidak mengharuskan nilai tertentu sebagai batasan. Dalam metode ini dana kas kecil berubah-ubah sesuai dengan transaksi yang menyangkut kas kecil. Dengan kata lain bisa diisi tidak sebesar yang dikeluarkan,bisa lebih besar atau lebih kecil dari saldo awal. Setiap terjadi perubahan jumlah uang dalam kas kecil selalu diadakan pencatatan.

2. Metode Dana Tetap (Imprest Fund Method)

Dalam metode ini dana kas kecil besarnya selalu tetap sesuai dengan yang telah ditetapkan oleh manajemen sehingga tidak setiap pengeluaran dicatat dalam kas kecil. Pencatatan dalam kas kecil hanya dilakukan jika ada penambahan/pengisian kembali dana kas kecil. Dalam hal ini kasir harus mengumpulkan bukti-bukti pengeluaran/pembelian dan membuat catatan/memo yang akan digunakan untuk mengajukan pengantian pada rekening kas besar.

\begin{tabular}{|c|c|c|}
\hline Transaksi & Imprest Fund Method & Fluctuating Fund Method \\
\hline $\begin{array}{l}\text { Pembentukan dana kas kecil } \\
\text { sebesar Rp. 5.000.000,- }\end{array}$ & $\begin{array}{cr}\text { Kas kecil } & 5.000 .000,-(\mathrm{Dr}) \\
\text { Kas } & 5.000 .000,-(\mathrm{Kr})\end{array}$ & $\begin{array}{cr}\text { Kas kecil } & 5.000 .000,-(\mathrm{Dr}) \\
\text { Kas } & 5.000 .000,-(\mathrm{Kr})\end{array}$ \\
\hline $\begin{array}{l}\text { Pengeluaran/pembayaran dana } \\
\text { kas kecil, misalnya : } \\
\text { 1. Membeli perlengkapan kantor } \\
\text { (ATK) Rp. 500.000,-- }\end{array}$ & Tidak dijurnal (Hanya memo) & $\begin{array}{l}\text { 1. Biaya Perlengkapan Kantor } \\
500.000,-(\mathrm{Dr}) \\
\text { Kas Kecil } 500.000,-(\mathrm{Kr})\end{array}$ \\
\hline
\end{tabular}




\begin{tabular}{|c|c|c|}
\hline Transaksi & Imprest Fund Method & Fluctuating Fund Method \\
\hline $\begin{array}{l}\text { 2. Pembayaran bahan bakar } \\
\text { kendaraan perusahaan Rp. } \\
\text { 200.000,- } \\
\text { 3. Membeli makan ringan untuk } \\
\text { tamu Rp. } 150.000,-\end{array}$ & & $\begin{array}{l}\text { 2.Biaya bahan bakar 200.000,- } \\
\text { (Dr) } \\
\text { Kas Kecil 200.000,- (Kr) } \\
\text { 3. Biaya Konsumsi 150.000,- (Dr) } \\
\text { Kas Kecil 150.000,- (Kr) }\end{array}$ \\
\hline Pengisian kembali dana kas kecil & $\begin{array}{l}\text { 1. Biaya Perlengkapan Kantor } \\
500.000,-(\mathrm{Dr}) \\
\text { 2. Biaya bahan bakar 200.000,- } \\
\text { (Dr) } \\
\text { 3. Biaya Konsumsi 150.000,- (Dr) } \\
\text { Kas } 850.000,-(\mathrm{Kr})\end{array}$ & $\begin{array}{cc}\text { Kas kecil } & 1.000 .000,-(\mathrm{Dr}) \\
\text { Kas } & 1.000 .000,-(\mathrm{Kr})\end{array}$ \\
\hline
\end{tabular}

\section{Tabel 2.1 Pencatatan Kas Kecil Menggunakan Metode Dana Tetap (Imprest Fund Method) dan Metode Dana Berubah (FluctuatingFund Method)}

\section{METODE PENELITIAN}

\subsection{Jenis Penelitian}

Jenis penelitian yang digunakan penulis adalah penelitian deskriptif, yang dilakukan dengan cara mengumpulkan data yang berhubungan dengan permasalahan yang dihadapi. Data merupakan keterangan-keterangan yang diperoleh dari penelitian atau melalui referensireferensi untuk mengetahui penerapan akuntansi dana kas kecil pada PT. Putra Karangetang. Penelitian yang tujuannya untuk menyajikan gambaran cara sistematis dan akurat mengenai fakta, sifat dari hubungan antar fenomena yang diteliti pada suatu perusahaan.

\subsection{Tempat dan Waktu Penelitian}

\subsubsection{Tempat Penelitian}

Penelitian ini dilakukan pada PT. Putra Karangetang, Jl. Arie Lasut No. 87.

\subsubsection{Waktu Penelitian}

Dengan melihat permasalahan yang akan diangkat dalam penelitian ini, maka lamanya waktu yang digunakan untuk meneliti adalah 2 (dua) bulan.

\subsection{Prosedur Penelitian}

Prosedur penelitian dalam penelitian ini adalah sebagai berikut :
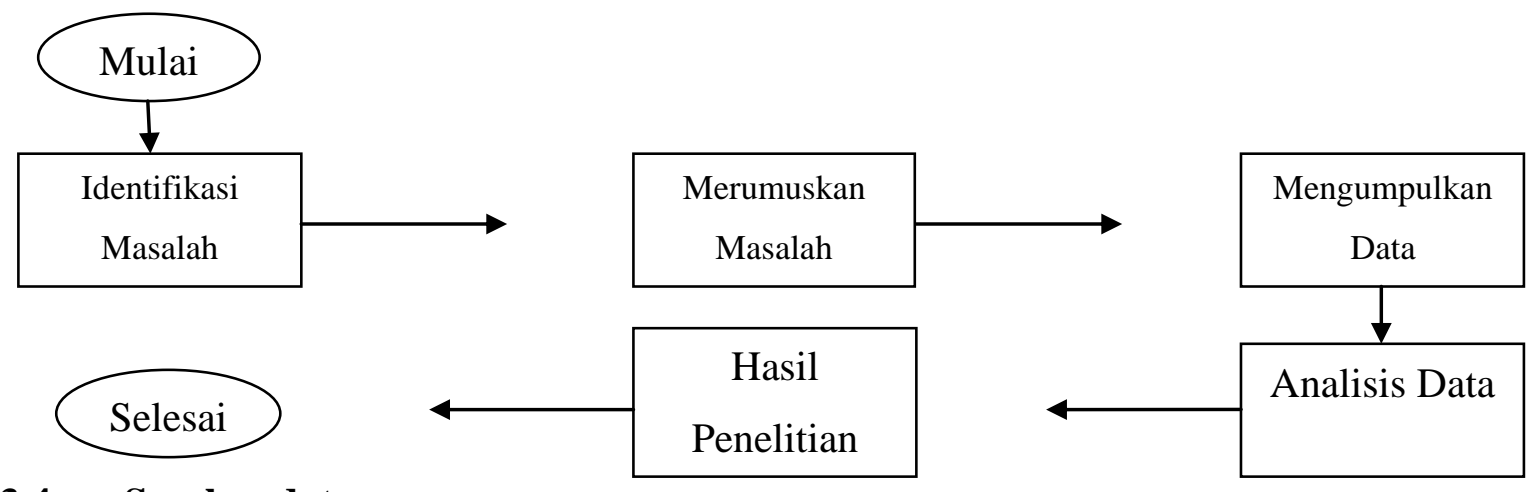

\subsection{Sumber data}

Sumber data dalam penelitian ini, yaitu : 
1. Data Primer, yaitu data yang diperoleh langsung oleh penulis dari objek penelitian dengan cara wawancara, dan data yang diambil dari perusahaan seperti buku kas kecil yang di pegang oleh seorang kasir untuk mencatat pengeluaran-pengeluaran dana kas kecil.

2. Data Sekunder, yaitu data yang berasal dari sumber atau pengamatan lain. Contohnya : buku-buku literatur yang digunakan sebagai acuan, jurnal-jurnal penelitian terdahulu yang berkaitan dengan akuntansi kas kecil.

\subsection{Teknik Pengumpulan Data}

Dalam penelitian ini, teknik pengumpulan data yang dilakukan dalam usaha mengumpulkan data dan informasi yaitu :

1. Penelitian lapangan (Field Researd Method). Dalam melakukan riset lapangan, penulis mengambil data-data langsung dari sumber data, sebagai pembanding untuk memproses keterangan dan kenyataan yang sebenarnya. Penelitian lapangan dilakukan dengan cara wawancara (Interview), yaitu dengan cara mewawancarai bagian pemegang dana kas kecil guna mendapatkan informasi dan data yang benar dan jelas.

2. Penelitian kepustakaan (Litbang Researd Method). Dalam menggunakan data-data kepustakaan yaitu buku-buku cetak yang berkaitan dengan penerapan akuntansi dana kas kecil dan jurnal-jurnal yang terdahulu, guna menyempurnakan penelitian.

\subsection{Metode Analisis Data}

Metode analisis yang digunakan untuk membahas permasalahan dalam penelitian ini adalah metode analisis deskriptif. Dimana penelitian deskriptif adalah suatu bentuk penelitian yang ditujukan untuk mendeskripsikan fenomena-fenomena yang ada, baik fenomena alamiah maupun fenomena buatan manusia. Dengan bahan analisis berupa buku kas kecil pada PT. Putra Karangetang.

\section{HASIL ANALISIS DAN PEMBAHASAN}

\subsection{Gambaran Umum Perusahaan}

PT. Putra Karangetang merupakan salah satu perusahaan penghasil tepung kelapa di Indonesia. Secara rutin hasil produksi tepung kelapa ini dikembangkan dan terus diteliti kualitas dan mutu. Penawaran, kemitraan, dan kerjasama pimpinan perusahaan membuahkan hasil. Tepung kelapa yang diproduksi dapat dipasarkan sampai ke mancanegara dengan lisensi-lisensi terkait yang menjamin kualitas dan mutu produk tepung kelapa. Perusahaan ini memiliki tempat memproduksi tepung kelapa yang terletak di desa Popontolen kecamatan Tumpaan Kabupaten Minahasa Selatan Provinsi Sulawesi Utara. Dalam proses produksi yang dilakukan menghasilkan tiga jenis tepung kelapa yang di hasilkan yaitu Medium (Tepung kelapa kasar), Fain (halus), dan Ekstra Fain (sangat halus).

\subsection{Hasil Penelitian}

\subsubsection{Analisis Buku Kas Kecil PT. Putra Karangetang}

Dana kas kecil (petty cash fund) biasanya tersedia disetiap perusahaan, hal ini dikarenakan banyak kebutuhan-kebutuhan yang sifatnya kecil yang tidak praktis jika dibayar dengan menggunakan cek. Begitu juga dengan PT. Putra Karangetang, perusahaan ini menyediakan dana kas kecil untuk membayar pengeluaran-pengeluaran yang sifatnya kecil dan segera.Akan menjadi sangat tidak praktis apabila perusahaan menggunakan cek atau transfer lewat rekening bank hanya untuk membayar pengeluaran-pengeluaranyang jumlahnya relatif kecil, seperti untuk membeli perangko, vas bunga, alas meja tamu yang ada di front office, biaya transportasi, dan lain sebagainya. 
Permintaan pengisian atau penggantian kembali kas kecil, yang diperlukan berupa cek yang dibuat dan disetujui oleh pejabat yang berwenang lalu dicairkan sebesar jumlah yang disetujui. Dana kas kecil pada PT. Putra Karangetang biasanya diisi kembali jika ada permintaan pengisian dana kas kecilserta tanpa waktu periodik. Ayat jurnal atas pembentukan dana kas kecil ini dibuat dengan cara mendebit akun kas kecil dan mengkredit akun kas.

Pemegang kas kecil pada PT. Putra Karangetang merupakan kasir kas kecil. Setiap kali kas kecil dibayarkan, kasir yang menangani dana kas kecil tidak mencatat setiap rincian pembayaran dalam bukti atau formulir. Perusahaan hanya langsung mencatat dalam jurnal atau disebut juga buku kas kecil.

PT. Putra Karangetang menggunakan metode fluktuasi, yaitu setiap terjadi pengeluaran uang dari kas kecil langsung dicatat. Pengeluaran-pengeluaran yang biasanya dibayar dengan menggunakan dana kas kecil seperti pembelian kertas, pembelian tinta komputer, uang transportasi, pembayaran rekening listrik, air, telepon, dan lain-lain. Namun dalam pembentukan dana kas kecil PT. Putra Karangetang, uang yang diserahkan kepada pemegang kas keciljumlahnya tidak tetap saat penggantian/pengisian kembali dan waktu pengisiannya juga tidak ditentukan. Seringkali dana kas kecil yang dipegang oleh kasir mengalami kelebihan.

Adapun batasan jumlah dana yang disediakan untuk pembentukan kas kecil oleh PT. Putra Karangetang maksimal Rp. 7.000.000,-. Pencatatan jurnal yang dilakukan oleh kasir adalah sebagai berikut :

Kas Kecil

Rp. 7.000.000,-

Kas

Rp. 7.000.000,-

Transaksi-transaksi pengeluaran kas kecil :

04 Mei 2017 : Membayar biaya transportasi karyawan ke DISNAKER provinsi sebesar Rp. 100.000,-

Biaya Transportasi 100.000,-

Kas Kecil 100.000,-

05 Mei 2017 : Membeli buku dan kertas sebesar Rp. 74.750,-

Biaya Supplies Kantor 74.750,-

Kas Kecil 74.750,-

10 Mei 2017 : Membayar biaya cleaning boiler sebesar Rp. 500.000,-

Biaya Reprarasi 500.000,-

Kas Kecil 500.000,-

15 Mei 2017 : Dana kas kecil diisi kembali sebesar Rp. 2.000.000,-

Kas Kecil

2.000.000,-

Kas

2.000.000,-

Setelah melihat hasil penelitian diatas, PT. Putra Karangetang sudah melakukan pencatatan dana kas kecil sesuai dengan metode yang digunakan yaitu metode fluktuasi, serta perusahaan sudah mengadakan pemisahan tugas antara kasir selaku pengelola seluruh kegiatan keuangan perusahaan dengan petugas yang memegang dana kas kecil, namun pemegang dana kas kecil dalam hal ini kasir kas kecil tidak menggunakan bukti/slip untuk pembayaran dana kas kecil dalam melakukan pengeluaran uang, hal ini dapat menyebabkan terjadinya penyelewengan dana kas kecil. Dalam hal ini pembentukan dana kas kecil ada langkah tambahan yang harus di tempuh oleh perusahaan yaitu menentukan besarnya dana kas kecil tersebut. Dana kas kecil dibentuk dengan menaksir terlebih dahulu banyak kas yang dibutuhkan untuk pembayaran-pembayaran dari dana tersebut selama satu periode, misalnya untuk satu minggu, dua minggu atau satu bulan kemudian cek diserahkan kepada kasir kas kecil dan diuangkan di bank. Kasir menyimpan dalam kotak laci dana kas kecil. Dalam hal pengeluaran atau pembayaran kas kecil, harus menggunakan bukti atau slip 
pembelian/pengeluaran agar supaya setiap pengeluaran uang dapat dikontrol dengan baik dan dapat mencegah terjadinya kebocoran dana kas kecil. Dan jika dana kas kecil sudah mencapai titik minimum maka harus segera diisi kembali supaya tidak menghambat pembelian/pengeluaran untuk kebutuhan-kebutuhan perusahaan dan dalam pembayaran tagihan.

\subsection{Pembahasan \\ PENERAPAN KAS KECIL DENGAN MENGGUNAKAN METODE DANA BERUBAH (FLUCTUATION FUND METHOD) MENURUT TEORI AKUNTANSI DAN PT. PUTRA KATANGETANG}

\begin{tabular}{|c|c|c|c|}
\hline No. & Teori & PT. Putra Karangetang & Ket. \\
\hline 1. & $\begin{array}{l}\text { Dana kas kecil disediakan untuk } \\
\text { membayar pengeluaran yang } \\
\text { jumlahnya relatif kecil dan tidak } \\
\text { ekonomis bila dibayar dengan cek }\end{array}$ & $\begin{array}{l}\text { Perusahaan menggunakan dana kas } \\
\text { kecil untuk membayar pengeluaran- } \\
\text { pengeluaran yang kecil dimana tidak } \\
\text { praktis jika dibayar dengan cek }\end{array}$ & $\begin{array}{l}\text { Sesuai } \\
\text { dengan teori }\end{array}$ \\
\hline 2. & $\begin{array}{l}\text { Dana kas kecil dipegang oleh } \\
\text { petugas atau karyawan yang khusus } \\
\text { menangani pengeluaran-pengeluaran } \\
\text { yang berhubungan dengan kas kecil, } \\
\text { yang disebut kasir kas kecil. }\end{array}$ & $\begin{array}{l}\text { Dana kas kecil dipegang oleh kasir } \\
\text { yang menangani pengeluaran- } \\
\text { pengeluaran yang berhubungan } \\
\text { dengan kas kecil }\end{array}$ & $\begin{array}{l}\text { Sesuai } \\
\text { dengan teori }\end{array}$ \\
\hline 3. & $\begin{array}{l}\text { Ada } 2 \text { metode yang berhubungan } \\
\text { dengan kas kecil yaitu metode } \\
\text { Fluktuasi dan metode Imprest }\end{array}$ & $\begin{array}{l}\text { Perusahaan menggunakan metode } \\
\text { Fluktuasi }\end{array}$ & $\begin{array}{l}\text { Sistem } \\
\text { memiliki } \\
\text { kelemahan } \\
\text { dalam } \\
\text { pengendalian } \\
\text { intern }\end{array}$ \\
\hline 4. & $\begin{array}{l}\text { Dalam metode Fluktuasi setiap } \\
\text { terjadi pengeluaran uang dari kas } \\
\text { kecil langsung dilakukan pencatatan }\end{array}$ & $\begin{array}{l}\text { Kasir langsung mencatat jika terjadi } \\
\text { pengeluaran kas kecil }\end{array}$ & $\begin{array}{l}\text { Sesuai } \\
\text { dengan teori }\end{array}$ \\
\hline 5. & $\begin{array}{l}\text { Jumlah dan waktu pengisian dana } \\
\text { kas kecil ditetapkan sesuai dengan } \\
\text { kebutuhan perusahaan }\end{array}$ & $\begin{array}{l}\text { Jumlah dan waktu pengisian dana kas } \\
\text { kecil tidak ditentukan, sehingga terjadi } \\
\text { kekosongan maupun kelebihan dana } \\
\text { kas kecil. }\end{array}$ & $\begin{array}{l}\text { Tidak sesuai } \\
\text { dengan teori }\end{array}$ \\
\hline 6. & $\begin{array}{l}\text { Setiap dilakukan pembayaran kas } \\
\text { kecil harus disertai slip atau bukti }\end{array}$ & $\begin{array}{l}\text { Perusahaan tidak menyediakan slip } \\
\text { atau bukti pengeluaran kas kecil. }\end{array}$ & $\begin{array}{l}\text { Tidak sesuai } \\
\text { dengan teori }\end{array}$ \\
\hline 7. & $\begin{array}{l}\text { Pembentukan dana kas kecil Rp. } \\
\text { 3.000.000,- dicatat dengan jurnal : } \\
\text { Kas Kecil } 3.000 .000 \\
\text { Kas } \quad 3.000 .000\end{array}$ & $\begin{array}{l}\text { Perusahaan membentuk dana kas kecil } \\
\text { Rp. 3.000.000,- dicatat dengan jurnal : } \\
\text { Kas Kecil } 3.000 .000 \\
\text { Kas } \\
\quad 3.000 .000\end{array}$ & $\begin{array}{l}\text { Sesuai } \\
\text { dengan teori }\end{array}$ \\
\hline 8. & 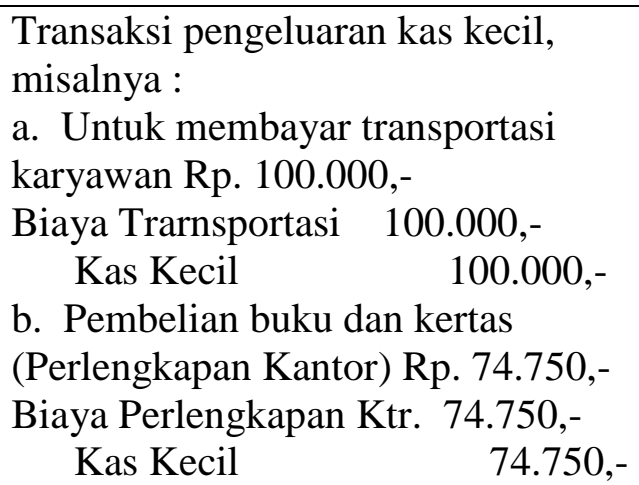 & $\begin{array}{l}\text { Perusahaan mencatat pengeluaran : } \\
\text { a.untuk membayar transportasi } \\
\text { karyawan Rp. } 100.000,- \\
\text { Biaya Trarnsportasi } 100.000,- \\
\text { Kas Kecil 100.000,- } \\
\text { b. Pembelian buku dan kertas } \\
\text { (Perlengkapan Kantor) Rp. } 74.750,- \\
\text { Biaya Perlengkapan Ktr. } 74.750,- \\
\text { Kas Kecil } \\
74.750,-\end{array}$ & $\begin{array}{l}\text { Sesuai } \\
\text { dengan teori }\end{array}$ \\
\hline
\end{tabular}




\begin{tabular}{|c|c|c|c|}
\hline No. & Teori & $\begin{array}{l}\text { PT. Putra Karangetang } \\
\end{array}$ & Ket. \\
\hline & $\begin{array}{l}\text { c. Untuk membayar biaya clearing } \\
\text { boiler Rp. } 500.000,- \\
\text { Biaya perbaikan } 500.000,- \\
\quad \text { Kas Kecil }\end{array}$ & $\begin{array}{l}\text { c.Untuk membayar biaya clearing } \\
\text { boiler Rp. } 500.000,- \\
\text { Biaya perbaikan } \\
\quad 500.000,- \\
\text { Kas Kecil }\end{array}$ & \\
\hline 9. & 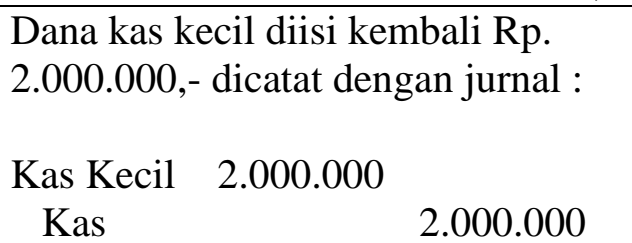 & 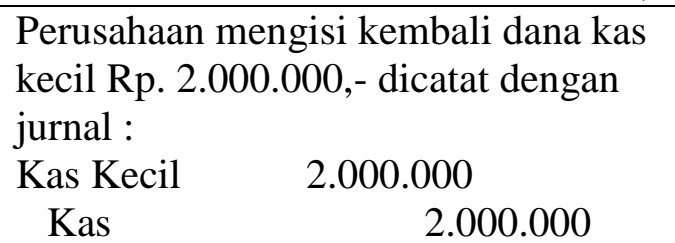 & $\begin{array}{l}\text { Sesuai } \\
\text { dengan teori }\end{array}$ \\
\hline
\end{tabular}

Berdasarkan tabel, bisa dilihat penerapan kas kecil dengan menggunakan metode fluktuasi di perusahaan, belum secara keseluruhan sesuai dengan teori akuntansi. Ketidaksesuai ini bisa menimbulkan masalah seperti kecurangan ataupun penyelewengan. Ada beberapa hal yang belum digunakan atau diterapkan perusahaan seperti pengisian dana kas kecil tidak ditentukan jumlahdan waktu pengisiannya. Didalam pembayaran kas kecil perusahaan tidak menyertai bukti atau slip pengeluaran kas kecil, hal ini bisa menyebabkan terjadinya kecurangan ataupun penyelewengan kas kecil. Dalam penerapan kas kecil juga sebaiknya menggunakan metode dana tetap agar supaya dapat di kontrol serta untuk pengendalian internal terhadap penggunaan dana kas kecil dapat dilaksanakan dengan baik oleh PT. Putra Karangetang. Dengan menerapkan metode dana tetap pada penggunaan dana kas kecil maka PT. Putra Karangetang juga bisa menetralisir penyalahgunaan maupun penyelewengan dana kas kecil serta memudahkan pengisian kembali dengan waktu yang ditetapkan dan dana kas kecil sesuai dengan kebutuhan.

Dana kas kecil menangani pengeluaran-pengeluaran yang bersifat kecil dan sering terjadi merupakan suatu potensi yang mengundang untuk penyalahgunaan maupun penyelewengan wewenang, untuk melakukan pengendalian internal terhadap penggunaan dana kas kecil PT. Putra Karangetangdapatmenerapkan penyertaan bukti-bukti pengeluaran dana kas kecil untuk menjadi dokumen penjelasan penggunaan dana sudah sesuai kebutuhan perusahaan. Bukti-bukit tersebut merupakan pertanggungjawaban pemegang dana kas kecil untuk penggunaan dana kas kecil.

Dalam penerapan akuntansi dana kas kecil disarankan PT. Putra Karangetang menggunakan metode dana tetap. Dalam metode ini dana kas kecil besarnya selalu tetap sesuai dengan yang telah ditetapkan manajemen sehingga tidak setiap pengeluaran dicatat dalam kas kecil. Dalam hal ini kasir harus mengumpulkan bukti-bukti pengeluaran/pembelian dan membuat catatan/memo yang akan digunakan untuk mengajukan pergantian pada rekening kas besar.

\section{KESIMPULAN DAN SARAN}

\subsection{Kesimpulan}

Berdasarkan hasil pembahasan dari penelitian yang telah dilakukan pada perusahaan PT. Putra Karangetang, dapat disimpulkan bahwa dana kas kecil yang dibentuk oleh perusahaan khusus disiapkan untuk membayar pengeluaran-pengeluaran yang bersifat kecil dan tidak praktis jika dibayar dengan menggunakan cek, serta pengeluaran atau pembyaran dana kas kecil dicatat atau dibuatkan jurnal setelah uang dikeluarkan. Adapun metode yang digunakan dalam penyelesaian dana kas kecil, oleh PT. Putra Karangetang yaitu metode fluktuasi, dimana dalam metode ini saldo rekening kas kecil tidak tetap (berfluktuasi), jumlah pengisian kembali tidak sesuai dengan pengeluaran-pengeluaran kas kecil. 


\subsection{Saran}

Saran agar dapat menjadi bahan masukan bagi perusahaan dalam mengelola dana kas kecil sebaiknya perusahaan menetapkan jumlah dan waktu pengisian sesuai dengan kebutuhan, serta menentukan jumlah maksimal dana yang tersedia. Dana kas kecil yang dikeluarkan atau dibayarkan sebaiknya menggunakan bukti atau slip pembayaran supaya tidak terjadi penyelewengan ataupun kecurangan. Sebaiknya PT. Putra Karangetang menerapkan sistem saldo tetap (imprest fund system) agar supaya pengendalian intern dapat dengan mudah dicapai.

\section{DAFTAR PUSTAKA}

Belkaoui, dan Ahmed Riahi. Accounting Theory Buku 1. 5th ed. Jakarta : Salemba Empat, 2012.

Harahap Sofyan Syahri, Teori Akuntansi, Edisi Revisi, PT. Grafindo Persada, Jakarta. 2013.

Hery. Analisis Laporan Keuangan Integrated and Comprehensive Edition. Jakarta: PT Grasindo, 2016.

Hery. Akuntansi Dasar 1 dan 2. Grasindo, Jakarta. 2014.

Hery. Akuntansi Aset, Liabilitas, dan Akuitas. Jakarta : PT Grasindo, 2014

Hery. Teori Akuntansi Suatu Pengantar. Jakarta: Lembaga Penerbit Fakultas Ekonomi Indonesia, 2013.

Ikatan Akuntansi Indonesia. (2015). Standar Akuntansi Keuangan. Jakarta: Salemba Empat.

Kasmir. Dasar-dasar Perbankan. Revisi 2014 ed. Jakarta: PT Raja Grafindo Persada.

Kartikahadi, Hans, Rosita Uli Sinaga, Merliyana Syamsul, Sylvia Veronica Siregar dan Ersa Tri Wahyuni. Akuntansi Keuangan Berdasarkan SAK Berbasis IFRS 2nd ed. Vol. 1. Jakarta: Ikatan Akuntansi Indonesia, 2016.

Kieso, Donald E., Jerry J. Weygent, and Terry D. Warfield. Intermedite Accounting IFRS Edition. 2nd ed. USA: JOHN WILEY, 2014.

Lili M. Sadeli, 2012, Dasar-Dasar Akuntansi, Jakarta, Penerbit: PT. Bumi Aksara.

Pontoh, Winston. 2013. Akuntansi Konsep dan Aplikasi. Halaman Moeka, Jakarta Barat.

Reeve, James M., Carl S. Warren, Jonathan E. Duchac, Ersa Tri Wahyuni, Gatot Soepriyanto, Amir Abadi Jusuf, and Chaerul D. Djakman. Pengantar Akuntansi Adaptasi Indonesia Buku 1. Jakarta: Indeks, 2013.

Stice, James D., and Earl K. Stice. Intermedite Accounting. Mason: South Western/Cengage Learning, 2014.

Warren, Carl S., James M. Reeve, and Jonathan Duchac. Financial Accounting.15th ed. USA: Cengage Learning, 2017.

Weygant, Jerry J., Paul D. Kimmel, and Donald E. Kieso. Financial Accounting IFRS Edition, 3rd ed. USA: Wiley, 2015. 